Syntax Literate: Jurnal Ilmiah Indonesia p-ISSN: 2541-0849

e-ISSN: 2548-1398

Vol. 5, No. 8, Agustus 2020

\title{
PENGEMBANGAN PERANGKAT PEMBELAJARAN FISIKA BERBASIS PROBLEM BASED LEARNING PADA METERI LISTRIK STATIS DAN DINAMIS
}

\author{
Novi Astrihani \\ Universitas Nahdlatul Ulama Cirebon Indonesia \\ Email: astrihaninovi@gmail.com
}

\section{Abstract}

This study aims to determine how the development of Vocational School physics learning tools based on Problem Based Learning for Vocational School students in class XI TKR, how the achievement of students after participating in the learning process using Problem Based Learning-based Vocational School Physics learning tools and to determine the effect of Problem Based Learning tools on static and dynamic electricity material that has been developed for learning outcomes. The method used is the analysis method, namely the data analysis technique carried out to determine the feasibility of Vocational School physics learning tools based on Problem Based Learning (PBL) in class XII Light Vehicle Engineering, which includes data instruments in the form of preliminary studies, validations, and product trials. The result of this research and development is a problem based learning Vocational School Physics learning tool consisting of a syllabus, lesson plans, teaching materials, assessment sheets, and student worksheets. The problems that arise in this study are related to the validity of the development of problem-based learning vocational high school physics learning tools for SMK class XII TKR students, the achievement of students after participating in the learning process using Problem Based Learning-based SMK Physics learning tools, and the effect of using the learning method using the Problem method. Based Learning on student learning outcomes.

Keywords: learning Media; Problem Based Learning; syllabus

\section{Abstrak}

Penelitian ini bertujuan untuk mengetahui bagaimana pengembangan perangkat pembelajaran fisika SMK berbasis Problem Based Learning untuk peserta didik SMK kelas XI TKR, bagaimana pencapaian peserta didik setelah mengikuti proses pembelajaran menggunakan perangkat pembelajaran Fisika SMK berbasis Problem Based Learning serta mengetahui pengaruh perangkat pembelajaran berbasis Problem Based Learning pada materi listrik statis dan dinamis yang telah dikembangkan terhadap hasil belajar. Metode yang digunakan yaitu metode analisis yakni teknik analisis data yang dilakukan untuk mengetahui kelayakan perangkat pembelajaran fisika SMK berbasis Problem Based learning (PBL) pada kelas XII Teknik Kendaraan Ringan, yang meliputi instrumen data berupa studi pendahuluan, validasi, dan uji coba produk. Hasil dari penelitian dan pengembangan ini adalah perangkat pembelajaran Fisika SMK berbasis problem based learning yang terdiri 
dari Silabus, RPP, Bahan Ajar, lembar penilaian dan Lembar Kerja Siswa. Masalah yang muncul dalam penelitian ini berkaitan dengan kevalidan pengembangan perangkat pembelajaran fisika SMK berbasis Problem Based Learning untuk peserta didik SMK kelas XII TKR, pencapaian peserta didik setelah mengikuti proses pembelajaran menggunakan perangkat pembelajaran Fisika SMK berbasis Problem Based Learning serta pengaruh penggunaan metode belajar menggunakan metode Problem Based Learning terhadap hasil belajar siswa.

Kata kunci : perangkat pembelajaran; Problem Based Learning; silabus

\section{Pendahuluan}

Pengembangan perangkat pembelajaran kurikulum saat ini sangatlah penting, diantaranya silabus, RPP, bahan ajar dan buku peserta didik. Perangkat tersebut dianggap belum memiliki ketersesuaian. Masih terdapat beberapa sub materi dalam buku guru yang tidak sesuai pada buku siswa. Selain itu, materi dalam buku pembelajaran peserta didik dinilai masih kurang, sehingga guru masih perlu menambahkan materi dari sumber lain.

Beberapa penelitian mengenai perangkat pembelajaran telah dilakukan diantaranya pengembangan perangkat pembelajaran Sains SMP berorientasi pendidikan berkarakter dengan model kooperatif pada materi sensitivitas indera peraba menunjukan bahwa peserta didik mampu belajar secara kelompok dan terlibat dalam proses berpikir kritis (Subekti, 2010).

Selain itu mengenai pengembangan perangkat pembelajaran berorientasi model pembelajaran diskusi pada pokok bahasan energi dan perubahannya untuk menumbuhkan sikap ilmiah peserta didik menyatakan bahwa model pembelajaran yang dikembangkan berkualitas baik dan dapat meningkatkan sikap ilmiah peserta didik (Wahyudiati, 2010).

Model pembelajaran adalah suatu perencanaan atau suatu pola yang digunakan sebagai pedoman dalam merencanakan pembelajaran di kelas atau pembelajaran dalam tutorial. Pembelajaran terpadu sebagai suatu konsep dapat dikatakan sebagai suatu pendekatan belajar mengajar yang melibatkan beberapa bidang studi untuk memberikan pengalaman bermakna kepada anak didik (Trianto, 2014).

Penelitian serupa juga dilakukan oleh Hadi Rohyana (2017) mengenai analisis proses berfikir kritis siswa pada Problem Based Learning berbanatuan edmodo untuk meningkatkan kemampuan berfikir kritis kelas VII. Hasil penelitian ini efektif untuk meningkatkan cara berfikir kritis siswa kelas VII.

Pada penelitian yang lain didapatkan simpulan. Bahwa adanya peningkatan hasil belajar siswa, prestasi kelas X AP 1 mencapai 76,66\%, kelas X AP 2 sebesar 80\% dari hasil analisis data tersebut menunjukan bahwa presentase siswa yang mencapai KKM lebih dari $75 \%$. Sehingga dapat disimpulkan bahwa perangkat pembelajaran yang dikembangkan sangat efektif dan dapat meningkatkan hasil belajar siswa (Rahmadi, 2015). Hasil belajar adalah kemampuan yang diperoleh anak setelah melalui kegiatan belajar (Jihad, 2013). 
Berdasarkan fenomena yang telah dijelaskan diatas maka dalam pembelajaran Fisika di SMK diperlukan adanya pengembangan suatu perangkat pembelajaran Fisika di SMK yang dapat menunjang pelaksanaan pembelajaran. Dengan adanya perangkat pembelajaran ini, diharapkan dapat memudahkan siswa dalam memahami konsepkonsep fisika dan dapat meng-kontekstual-kan teori pembelajaran fisika pada keahlian yang dimilikinya. Pengembangan produk yang pernah dilakukan kemudian divalidasi oleh dua dosen ahli dan dua pendidik. Hasil dari validasi menunjukan bahwa perangkat pembelajaran berupa silabus, RPP, Bahan Ajar, dan instrument penilaian sudah layak untuk digunakan dalam proses pembelajaran (Rahayu, 2015).

Problem Based Learning (PBL) merupakan model pembelajaran yang menyajikan masalah kontekstual sehingga merangsang peserta didik belajar dalam kelompok untuk memecahkan masalah dari permasalahan dunia nyata dan mengikat peserta didik pada rasa ingin tahu terhadap pembelajaran, sehingga mereka memiliki model belajar sendiri (Kebudayaan, 2013). Sejalan dengan hal tersebut (Norsalisa \& Widiyaningrum, 2013) menyatakan bahwa Problem Based Learning (PBL) merupakan pembelajaran yang menghadapkan siswa pada masalah dunia nyata untuk memulai pembelajaran. Peserta didik dapat memperoleh informasi dari lingkungan sekitar mereka berdasar pada permasalahan yang ada dalam kehidupan sehari-hari mereka agar memiliki kemampuan memecahkan masalah (Setyorini, Sukiswo, \& Subali, 2011).

Berdasarkan hasil penelitian dan pembahasan dapat disimpulkan bahwa model Problem Based Learning (PBL) dapat meningkatkan kemampuan berfikir kritis siswa. Hal ini dapat dilihat bahwa 75\% siswa memiliki kemampuan berfikir kritis, 7,5\% siswa memiliki kemampuan sangat kritis, psikomotorik siswa memiliki nilai rerata 82,75 dalam kategori sangat aktif, dan afektif siswa mempunyai nilai rerata sebesar 73,38 yang termasuk kategori baik. Oleh karena itu, para guru diharapkan mampu memvariasikan model pembelajaran yang dapat menghindari rasa bosan dan tercipta suasana yang menyenangkan. Model Problem Based Learning (PBL) dapat dijadikan solusi untuk meningkatkan kemampuan siswa pada mata pelajaran Fisika di SMK.

Penelitian ini dilaksanakan di SMK SIMA BANGSA. SMK SIMA BANGSA ini sudah memiliki labolatorium komputer dan proyektor sehingga dapat menggunakan fasilitas yang ada guna memudahkan penyampaian materi pelajaran Fisika. Pentingnya proyektor untuk menyampaikan materi khususnya materi gelombang dan bunyi, diharapkan siswa dapat menganalogikan gelombang dan bunyi melalui penayangan slide presentation. Guru yang mengajar pelajaran fisika belum sesuai dengan pedagogiknya sehingga kurangnya kompetensi penyampaian materi fisika. KKM kelas XI TKR di SMK Sima Bangsa adalah 75. Nilai Rerata Ujian Akhir Semester (UAS) kelas XI TKR SMK Sima Bangsa adalah 64. Dilihat dari KKM dan rerata yang belum sesuai sehingga perlu adanya pembelajaran yang aktif, kreatif, dan inovatif. Dengan menggunakan model pembelajaran Problem Based Lerning ini peserta didik dapat memperoleh informasi dari lingkungan sekitar mereka berdasarkan permasalahan yang ada dalam kehidupan sehari-hari mereka, agara memiliki kemampuan memecahkan masalah. 


\section{Metode Penelitian}

Tahap analis kebutuhan guru dan siswa akan dilakukan di SMK Sima Bangsa dan akan diujicobakan di SMK Sima Bangsa yang beralamat di jalan arya salingsingan No. 17 Desa Waruroyom Kecamatan Depok Kabupaten Cirebon dengan materi pokok listrik statis dan dinamis pada kelas XI Teknik Kendaraan Ringan. Penelitian dan pengembangan ini akan dilakukan pada Tahun Pelajaran 2017/2018.

Teknik analisis data dilakukan untuk mengetahui kelayakan perangkat pembelajaran fisika SMK berbasis Problem Based learning (PBL) pada kelas XII Teknik Kendaraan Ringan, yang meliputi instrumen data berupa studi pendahuluan, validasi, dan ujicoba produk.

\section{Hasil dan Pembahasan}

Hasil dari penelitian dan pengembangan ini adalah perangkat pembelajaran Fisika SMK berbasis problem based learning yang terdiri dari Silabus, RPP, Bahan Ajar, lembar penilaian dan Lembar Kerja Siswa. SK yang menjadi bahan kajian perangkat pembelajarannya adalah SK 1 yaitu "Menginterpretasikan Listrik Statis Dan Dinamis". KD yang menjadi bahan kajian perangkat pembelajarannya adalah KD 1 yaitu,"membedakan konsep listrik statis dan dinamis". Penelitian dan pengembangan ini dilakukan dengan menggunakan Borg and Gall dari tahap 1 sampai dengan tahap 7. Data hasil dari tahap prosedur penelitian pengembangan yang dilakukan adalah sebagai berikut:

\section{Hasil Tahap Studi Pendahuluan}

a. Studi pustaka

Hasil studi pustaka merupakan hasil analisis dari SK-KD mata pelajaran fisika pada kelas XII SMK Teknologi dan Rekayasa yang mengacu pada standar isi (Permendiknas Nomor 22 Tahun 2006). Hasil analisis ini ditujukan untuk menentukan Standar Kompetensi, Kompetensi Dasar, Materi Pembelajaran yang memungkinkan untuk dipilih sebagai acuan pengembangan perangkat pembelajaran. Hasil studi pustaka ini dapat dilihat pada Lampiran.

b. Survei lapangan

Selain data analisis SK dan KD, pada tahap studi pendahuluan juga didapatkan data hasil observasi sekolah yang akan dijadikan objek penelitian yaitu, SMK SIMA BANGSA. Ada beberapa hal yang menjadi kriteria observasi adalah kelengkapan perangkat pembelajaran yang dimiliki, kelengkapan sarana dan prasarana yang dimiliki sekolah dalam belajar dan pembelajaran, dan kemampuan peserta didik.

Berdasarkan data hasil observasi yang telah dilakukan, diperoleh: 1). Perangkat pembelajaran yang dimiliki oleh guru dari sekolah tersebut belum lengkap, perangkat pembelajaran yang sudah ada disekolah tersebut terdiri dari: RPP, Silabus, Lembar penilaian, dan bahan ajar; 2) perangkat pembelajaran yang tidak saling terpaduan dan tidak mendukung pembelajaran yang kontektual serta belum mengintegrasikan dalam metode pembelajaran Problem Based 
Learning; 3) sarana prasaran sekolah yang belum lengkap; 4) kemampuan akademik dan motivasi belajar peserta didik yang masih rendah.

\section{Hasil Tahap Perencanaan}

Berdasarkan hasil tahap studi pendahuluan yang telah dilakukan, maka spesifikasi khusus perangkat pembelajaran yang akan dikembangkan adalah sebagai berkut:

a. SK yang akan dipilih untuk dikembangan perangkat pembelajarannya adalah SK 1 yaitu, Menginterpretasikan Listrik Statis Dan Dinamis kelas XII TKR SMK. Terdapat arahan bagi guru untuk mendidik dengan menggunakan metode pembelajaran Problem Based Learning dalam pelajaran fisika materi listrik statis dan dinamis.

b. Terdapat keterpaduan antara Silabus, RPP, bahan ajar, dan Lembar Kerja Siswa. Berikut adalah perencanaan pembelajaran yang dijelaskan dalam perencanaan SK dan KD, indikator pembelajaran, tujuan pembelajaran, model pembelajaran, metode pembelajaran, dan peta konsep pembelajaran Problem Based Learning:

Pemilihan SK dan KD mengacu pada standar isi (Permendiknas Nomor 22 Tahun 2006) yang disesuaikan dengan pola dari mudah ke sukar, konkret ke abstrak, dan dengan pendekatan terpadu sehingga akan mudah ditemukan pola keterkaitan. Indikator pembelajaran disesuaikan dengan pencapaian KD yang diinginkan, dirumuskan dengan cakupan kompetensi yang terkandung di dalam $\mathrm{KD}$, dan dikembangkan sesuai dengan hakikat sains menggunakan kata kerja operasional yang dapat diukur dan terdiri dari indikator kognitif produk yang tahapannya dimulai dari $\mathrm{C} 1$ sampai $\mathrm{C} 6$, kognitif proses yang tahapannya dimulai dari P1 sampai P5, psikomotorik, serta indikator ketercapaian afektif.

Tujuan pembelajaran disesuaikan dengan Permendiknas Nomor 41 Tahun 2008 tentang standar proses, yang didalamnya menggambarkan proses dan hasil belajar yang diharapkan dapat tercapai oleh peserta didik sesuai dengan kompetensi dasar, dikembangkan sesuai dengan hakikat sains dan terdiri dari tujuan pembelajaran kognitif produk, kognitif proses, psikomotorik, dan afektif.

Berdasarkan tujuan pembelajaran, materi pembelajaran, karakteristik peserta didik, dan fasilitas yang tersedia, maka model pembelajaran yang cocok untuk digunakan adalah Problem Based Learning. Metode pembelajaran dipilih dengan mempertimbangkan pengembangan kemampuan peserta didik agar lebih kreatif, inovatif, dan dikondisikan pada pembelajaran yang bersifat problematis, sehingga digunakan metode tugas, kerja kelompok, diskusi, tanya jawab, dan percobaan/eksperimen.

c. Analisis konsep digunakan untuk mengidentifikasi konsep-konsep yang akan diajarkan. Konsep yang diajarkan diawali dari Listrik dan diakhiri dengan penerapan alat-alat elektronik. Analisis knsep disajikan pada gambar 1 Peta konsep. 


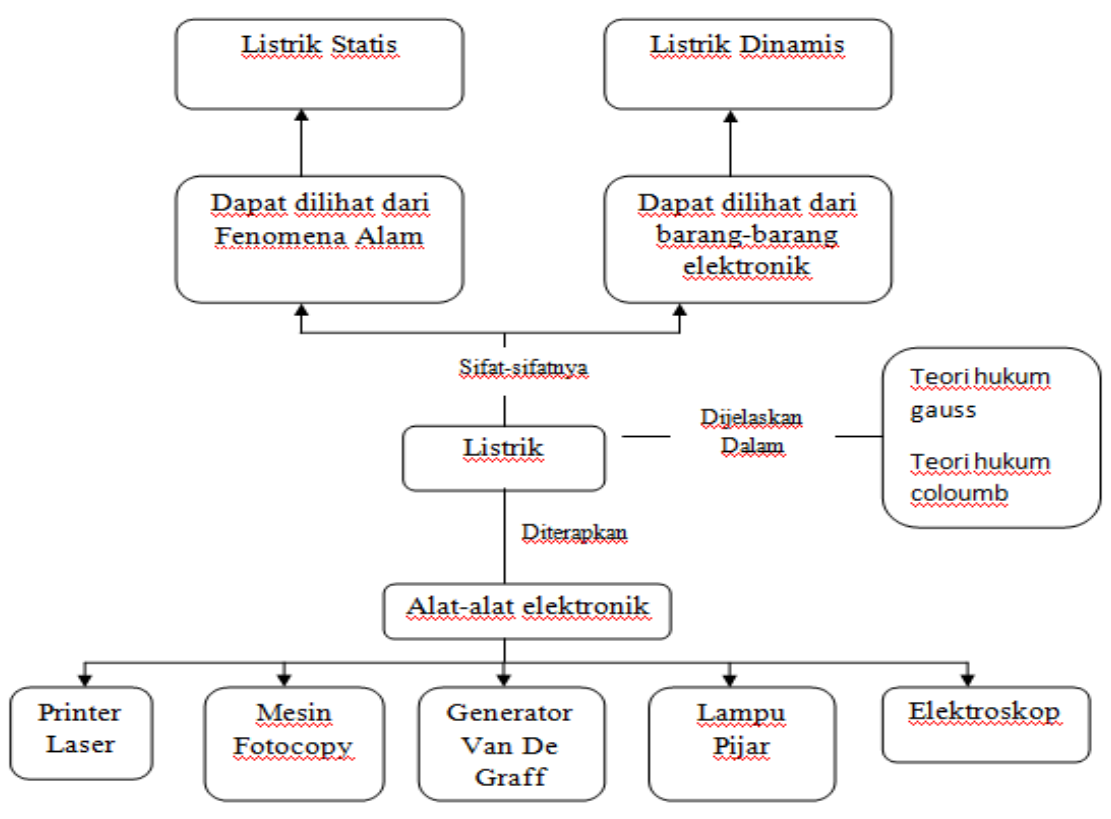

Gambar 1 Peta Konsep

Contoh rencana pembelajaran yang lebih lengkap disajikan pada lampiran.

\section{d. Analisis Hasil Pretes}

Di analisis hasil pretes, melakukan uji 35 soal pilihan ganda yang dijadikan sebagai tolak ukur untuk mendapatkan soal yang valid guna mendapatkan soal yang kemudian akan diujikan pada post-tes. Analisis soal di ujikan pada 39 siswa TKR dengan jumah soal 35 soal yang valid adalah 30 soal pilihan ganda.

\section{Hasil Tahap Penyusunan Draf I (Desain Produk Awal)}

a. Silabus

Desain awal silabus yang telah dikembangkan oleh sekolah, terdapat komponen-komponen berikut:

1) Nama mata pelajaran, jenjang sekolah, kelas dan semester dengan jelas sehingga ada kejelasan tentang tingkat pengetahuan prasyarat, pengetahuan awal dan karakteristik peserta didik yang akan diberi pelajaran.

2) Standar kompetensi yang merupakan pernyataan tentang pengetahuan, keterampilan dan sikap yang harus dikuasai oleh peerta didik serta tingkat penguasaan yang diharapkan adanya perubahan setelah pembelajaran dalam mempelajari suatu mata pelajaran.

3) Kompetensi dasar, peserta didik harus menguasai kompeternsi dasarnya terlebih dahulu sebelum menguasai Standar yang telah ditetapkan oleh tiap mata pelajaran dengan perincian atau penjabaran lebih lanjut dari standar kompetensi. 
4) Materi pokok sebagai sarana pencapaian kompetensi dasar dan yang akan dinilai menggunakan instrumen penilaian berdasarkan indikator pencapaian hasil belajar.

5) Pengalaman belajar peserta didik, yaitu aktivitas belajar yang perlu dilakukan oleh peserta didik dalam mencapai penguasaan standar kompetensi, kompetensi dasar dan materi pembelajaran.

6) Penjabaran kompetensi dasar menjadi indikator, indikator merupakan kompetensi dasar secara spesifik yang dijadikan ukuran untuk mengetahui ketercapaian hasil pembelajaran, berupa indikator kognitif proses dan kognitif produk.

7) Penjelasan indikator ke dalam instrumen penilaian meliputi bentuk instrumen dan contoh instrumen.

b. RPP

Desain awal RPP yang telah dikembangkan disekolah, terdapat komponenkomponen berikut:

1) Standar kompetensi dan kompetensi dasar.

2) Indikator pencapaian kompetensi dasar tersebut, yang berupa indikator kognitif.

3) Alokasi waktu yang diperlukan untuk mencapai kompetensi dasar.

4) Rumusan tujuan pembelajaran yang ingin dicapai dalam pembelajaran fisika.

5) Materi pembelajaran yang akan diberikan pada peserta didik untuk mencapai tujuan pembelajaran yang telah dirumuskan.

6) Metode pembelajaran yang dapat mendukung sifat materi dan tujuan pembelajaran.

7) Langkah-langkah kegiatan pembelajaran yang mengikuti sintaks Problem Based Learning dan memadukan Lembar Kerja Siswa dan Bahan Ajar serta mengitegrasikan metode pembelajaran Problem Based Learning.

8) Membagi setiap jam pertemuan berdasarkan pada satuan tujuan pembelajaran atau sifat/jenis materi pembelajaran bila untuk mencapai satu kompetensi dasar membutuhkan alokasi waktu lebih dari 8 jam pelajaran.

9) Sumber atau media pembelajaran secara konkret untuk setiap bagian/pertemuan.

10) Teknik penilaian.

c. Bahan Ajar

Desain awal bahan ajar yang telah dikembangkan, terdapat komponenkomponen berikut:

1) Kata-kata sains yang dapat dibaca pada uraian materi pelajaran.

2) Tujuan yang memuat tujuan yang hendak dicapai setelah mempelajari materi bahan ajar. 
3) Materi pelajaran berisi uraian materi yang harus dipelajari.

4) Bagan atau gambar yang mendukung ilustrasi pada uraian materi.

5) Uji diri setiap materi pokok, masalah-masalah dalam kehidupan seharihari yang perlu didiskusikan.

d. Lembar Kegiatan Peserta Didik (LKS)

Desain awal LKPD yang telah dikembangkan, terdapat komponenkomponen berikut:

1) Judul: Berupa judul suatu topik pembelajaran.

2) Tujuan Pembelajaran: Berupa tujuan pembelajaran khusus (TPK), yang pengembangannya melalui Analisis Materi Pelajaran (AMP).

3) Wacana-wacana materi prasyarat berupa Pendahuluan, sebagai pengetahuan dan keterampilan yang merupakan bekal awal pembelajar.

4) Kegiatan pralaboratorium: Berupa penyajian masalah yang harus disampaikan guru untuk dipecahkan oleh peserta didik dengan prosedur ilmiah.

5) Soal latihan: soal latihan yang disajikan lebih ke Problem Based Learning dan penyediaan kolom untuk jawaban.

6) Kegiatan laboratorium: Berupa kolom isian kegiatan kerja yang telah direncanakan dan telah diperiksa guru, bimbingan pengumpulan data, bimbingan analisis data, dan bimbingan penarikan kesimpulan. Semua bimbingan berupa pertanyaan-pertanyaan yang jawabannya merupakan tuntunan melakukan setiap langkah prosedur ilmiah.

\section{Hasil Tahap Validasi Produk Awal (Draf I)}

Tabel 1, 2, 3 menyajikan hasil validasi terhadap Draf I dan saran yang diberikan oleh masing-masing validator serta revisi tahap 1 yang diperoleh dari 2 orang dosen ahli pendidikan fisika, 1 orang guru Fisika SMK, dan 2 orang teman sejawat.

Tabel 1 Hasil Validasi Produk Awal Oleh Dosen Ahli

\begin{tabular}{lllll}
\hline $\begin{array}{l}\text { Validator } \\
\text { Produk }\end{array}$ & Dosen 1 & Dosen 2 & Rerata & Kategori \\
\hline Silabus & 4 & 4 & 4 & SB \\
RPP & 4 & 4 & 4 & SB \\
LOHBS & 4 & 4 & 4 & SB \\
Bahan Ajar & 4 & 4 & 4 & SB \\
LKPD & 4 & 4 & 4 & SB \\
\hline
\end{tabular}

Tabel 2 Hasil Validasi Produk Awal Oleh Guru

\begin{tabular}{cccc}
\hline $\begin{array}{c}\text { Validator } \\
\text { Produk }\end{array}$ & Guru & Rerata & Kategori \\
\hline Silabus & 4 & 4 & SB \\
RPP & 4 & 4 & SB \\
Bahan Ajar & 4 & 4 & SB \\
LKS & 4 & 4 & SB \\
\hline
\end{tabular}


Tabel 3 Hasil Validasi Produk Awal Oleh Teman Sejawat

\begin{tabular}{ccccc}
\hline $\begin{array}{c}\text { Validator } \\
\text { Produk }\end{array}$ & Sejawat 1 & Sejawat 2 & Rerata & Kategori \\
\hline Silabus & 4 & 4 & 4 & SB \\
RPP & 4 & 4 & 4 & SB \\
Bahan Ajar & 4 & 4 & 4 & SB \\
LKS & 4 & 4 & 4 & SB \\
\hline
\end{tabular}

Tabel 1, 2 dan 3 Menunjukkan hasil penilaian tiap perangkat yang diperoleh dari validator. Rerata yang diperoleh untuk penilaian silabus adalah 4 dengan kategori "Sangat Baik", rerata yang diperoleh untuk penilaian RPP adalah 4 dengan kategori "Sangat Baik", rerata yang diperoleh untuk penilaian Bahan Ajar adalah 4 dengan kategori "Sangat Baik", dan rerata yang diperoleh untuk penilaian LKS adalah 4 dengan kategori "Sangat Baik". Selengkapnya dari hasil validasi terdapat pada Lampiran.

\section{Hasil Tahap Uji Coba}

Perangkat pembelajaran yang dikembangkan diujicobakan selama 6 jam pelajaran $(5 \times 45)$ dari total alokasi waktu yang sesungguhnya 10 jam pelajaran. Tahap uji coba terbagi menjadi 2, yaitu tahap uji coba terbatas dan uji coba diperluas

\section{Kesimpulan}

Pengembangan perangkat pembelajaran Pengembangan Perangkat Pembelajaran Fisika Berbasis Problem Based Learning Pada Meteri Listrik Statis Dan Dinamis Untuk Meningkatkan Hasil Belajar Siswa Serta Evektivitasnya dilakukan dengan menggunakan metode Research and Development oleh Borg \& Gall melalui tahapantahapan: Research And Information Collecting (melakukan pengumpulan informasi dan membuat kerangka kerja penelitian), Planning (melakukan perencanaan dan tujuan penelitian), Develop Preliminary Form Of Product (mengembangkan bentuk produk awal dan memvalidasi produk), Preliminary Field Testing (melakukan uji coba lapangan permulaan), Main Product Revision (melakukan revisi terhadap produk utama), Main Field Testing Product Revision (melakukan uji coba lapangan utama), dan Operational Product Revision (melakukan revisi terhadap uji coba lapangan utama).

Kualitas produk Pembelajaran Fisika Berbasis Problem Based Learning Pada Meteri Listrik Statis Dan Dinamis Untuk Meningkatkan Hasil Belajar Siswa Serta Evektivitasnya yang dikembangkan mendapatkan nilai dengan rerata 4 dan berkategori "sangat baik".

Pencapaian hasil belajar peserta didik setelah mengikuti proses pembelajaran menggunakan Pembelajaran Fisika Berbasis Problem Based Learning Pada Meteri Listrik Statis Dan Dinamis Untuk Meningkatkan Hasil Belajar Siswa Serta Evektivitasnya mengalami peningkatan. 


\section{BIBLIOGRAFI}

Jihad, Asep. (2013). Evaluasi pembelajaran. Multi Pressindo.

Kebudayaan, Kementrian Pendidikan. (2013). Materi Pelatihan Guru Implementasi Kurikulum 2013. Nuh, M.(2013). Kurikulum.

Norsalisa, Eko, \& Widiyaningrum, Priyantini. (2013). Pengembangan Media Pembelajaran Zat Adiktif dan Psikotropika Berbentuk Komik Kontekstual di SMP. Journal of Innovative Science Education, 2(1).

Rahayu, Rina. (2015). Pengembangan Perangkat Pembelajaran IPA Berbasis Problem Based Learning Di SMP. Jurnal Kependidikan: Penelitian Inovasi Pembelajaran, 45(1).

Rahmadi, Furdan. (2015). Pengembangan perangkat pembelajaran berbasis pemecahan masalah berorientasi pada kemampuan penalaran dan komunikasi matematika. Jurnal Pendidikan Matematika, 10(2), 137-145.

Setyorini, U., Sukiswo, S. E., \& Subali, B. (2011). Penerapan model problem based learning untuk meningkatkan kemampuan berpikir kritis siswa SMP. Jurnal Pendidikan Fisika Indonesia, 7(1).

Subekti, Hasan. (2010). Pengembangan Perangkat Pembelajaran Sains SMP Berorientasi Pendidikan Berkarakter Dengan Model Kooperatif Pada Materi Sensitifitas Indera Peraba. Proceeding of The 4 Th International Confrence on Teacher Education.

Trianto, T. (2014). Model Pembelajaran Terpadu; Konsep, Strategi dan Implementationnya dalam KTSP. Jakarta: Bumi Aksara.

Wahyudiati, Dwi. (2010). Pengembangan perangkat pembelajaran berorientasi model pembelajaran diskusi pada pokok bahasan energi dan perubahannya untuk menumbuhkan sikap ilmiah siswa. Badan Penelitian Dan Pengembangan. 